\title{
НОВІ ДІАГНОСТИЧНІ ОЗНАКИ В КОМП'ЮТЕРНИХ СИСТЕМАХ ДІАГНОСТИКИ ФУНКЦІОНАЛЬНОГО СТАНУ СЕРЦЕВО-СУДИННОЇ СИСТЕМИ людини
}

\author{
В. П. Марценюк, А. С. Сверстюк, Н. В. Вар'ян \\ Тернопільський державний медичний університет імені І. Я. Горбачевського
}

У роботі запропоновано нові діагностичні ознаки для потреб автоматизованої кардіодіагностики у вигляді коефріцієнтів розкладу статистичних оцінок синхронно зареєстрованих кардіосигналів в базисі тригонометричних функцій.

Ключові слова: синхронно зареєстровані кардіосигнали, статистична обробка, діагностичні ознаки.

\section{НОВЫЕ ДИАГНОСТИЧЕСКИЕ ПРИЗНАКИ В КОМПЬЮТЕРНЫХ СИСТЕМАХ ДИАГНОСТИКИ ФУНКЦИОНАЛЬНОГО СОСТОЯНИЯ СЕРДЕЧНО-СОСУДИСТОЙ СИСТЕМЫ ЧЕЛОВЕКА}

\begin{abstract}
В. П. Марценюк, А. С. Сверстюк, Н. В. Варьян
Тернопольский государственный медицинский университет имени И. Я. Горбачевского

В работе предложены новые диагностические признаки для автоматизированной кардиодиагностики в виде коэффициентов разложения статистических оценок синхронно зарегистрированных кардиосигналов в базисе тригонометрических функций.
\end{abstract}

Ключевые слова: синхронно зарегистрированные кардиосигналы, статистическая обработка, диагностические признаки

\section{NEW DIAGNOSTIC CRITERIA IN COMPUTER SYSTEMS OF DIAGNOSTICS OF FUNCTIONAL CARDIOVASCULAR SYSTEM OF HUMAN}

\author{
V. P. Martsenyuk, A. S. Sverstiuk, N. V. Varyan \\ Ternopil State Medical University by I.Ya. Horbachevsky
}

The new diagnostic criteria for the automatized cardiodiagnostics as the coefficients of the statistic assessment of synchronously registered cardiosignals in terms of trigonometric functions are analyse $\mathrm{d}$ and suggested in the paper.

Key words: synchronously registered cardiosignals, statistical processing, diagnostic criteria.

Вступ. При розробці систем автоматизованої кардіодіагностики, важливим етапом є обгрунтування діагностичних (прогностичних) ознак, за якими буде здійснюватись діагностика (прогноз) функціонального стану серцево-судинної системи людини. У роботах $[1,2]$ обгрунтовано та верифіковано математичну модель широкого класу кардіосигналів у вигляді циклічного випадкового процесу, а також модель сукупності синхронно зареєстрованих кардіосигналів (СЗКС) у вигляді вектора циклічних ритмічно пов'язаних випадкових процесів. У роботах $[3,4]$ розроблені методи статистичного аналізу, зокрема сумісного статистичного аналізу, кардіосигналів в ком(C) А. С. Сверстюк, Н. В. Вар'ян п' ютерних діагностичних системах. В результаті застосування цих методів статистичної обробки кардіосигналів, отримуються статистичні оцінки їх ймовірнісних характеристик, зокрема, математичного сподівання, дисперсії, автокореляційної функції, взаємної кореляційної функції, функції розподілу і т.д. Однак така значна множина характеристик досліджуваних кардіосигналів не може бути використана для автоматизованої кардіодіагностики, оскільки це вимагає значних затрат обчислювальної продуктивності комп'ютерної діагностичної системи. Дана робота присвячена обгрунтуванню необхідної мінімальної сукупності діагностичних ознак, які $є$ 
чутливими до зміни стану серцево-судинної системи людини.

Основна частина. У багатьох експериментах зі статистичної обробки широкого класу кардіосигналів підтверджено факт несуперечності нормальному закону розподілу сукупності синхронно зареєстрованих кардіосигналів, а саме, шляхом застосування $x^{2}$ -

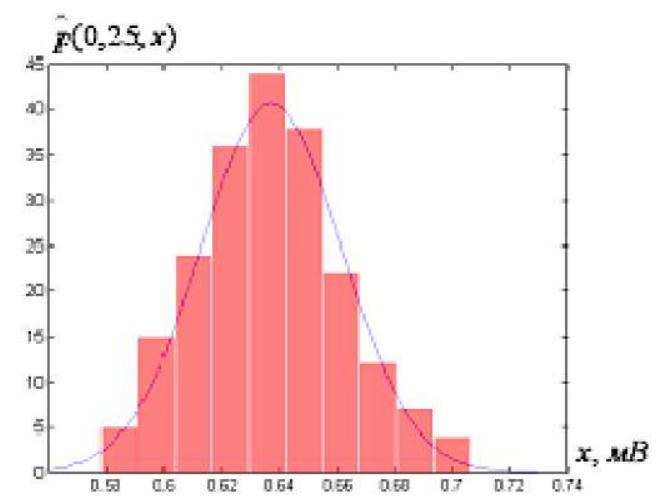

a тесту встановлено, що кардіосигнали із довірчою ймовірністю 0,95 (рівень значимості дорівнює 0,05) не суперечать гіпотезі про нормальність їх розподілу. Як приклад, на рисунку 1 подано графіки перерізів реалізації оцінки одновимірної функції щільності розподілу (гістограми) та їх апроксиманти для електрокардіосигналу.

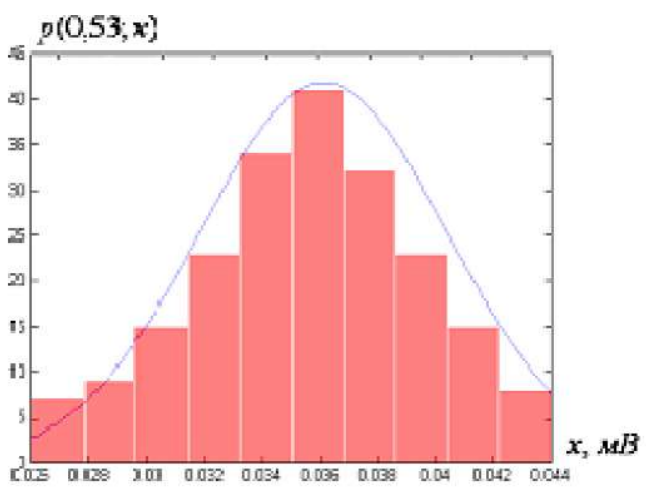

6

Puc. 1. Графіки перерізів реалізації оцінки одновимірної функції щільності розподілу (гістограми) та їх апроксиманти: амплітуда зубця R (a) та амплітуда зубця T (б).

Факт нормальності розподілу кардіосигналів вказує на достатність використання статистичних оцінок перших двох моментних функцій досліджуваних кардіосигналів, а саме їх математичних сподівань та кореляційних функцій.

3 метою зменшення розмірності простору діагностичних ознак як діагностичні ознаки пропонується використовувати коефіцієнти ортогональних розкладів статистичних оцінок математичного сподівання у ряд Фур'є. Так, реалізацію статистичної оцінки $m_{\xi}(t), t \in[0, T)$ математичного сподівання досліджуваного кардіосигналу можна розкласти в ряд Фур'є у комплексній формі, а саме:

$$
\begin{gathered}
m_{\xi}(t)=\sum_{n=-\infty}^{\infty} c_{n} \cdot e^{i \frac{2 \pi}{T} t \cdot n}, t \in[0, T) \\
\text { де }\left\{e^{i \frac{2 \pi}{T} t \cdot n}, n \in \mathbf{Z}\right\} \text { - ортогональний базис на об- }
\end{gathered}
$$

ласті $[0, T)$; множина $\left\{c_{n}, n \in \mathbf{Z}\right\} \in$ множиною спектральних коефіцієнтів, які визначаються згідно із формулою:

$c_{n}=\frac{1}{T} \int_{0}^{T} m_{\xi}(t) \cdot e^{-i \frac{2 \pi}{T} t \cdot n} d t, n \in \mathbf{Z}$.
Коефіцієнти $\left\{c_{n}, n \in \mathbf{Z}\right\}$ загалом є комплексними, а саме, мають таке зображення:

$c_{n}=a_{n}-i \cdot b_{n}, n \in \mathbf{Z}$,

де множини коефіцієнтів $\left\{a_{n}, n \in \mathbf{Z}\right\}$ та $\left\{b_{n}, n \in \mathbf{Z}\right\}$ $\epsilon$, відповідно, косинусним та синусним спектрами реалізації статистичної оцінки математичного $m_{\xi}(t)$ сподівання, які визначаються так:

$a_{n}=\operatorname{Re}\left\{c_{n}\right\}=\frac{1}{T} \int_{0}^{T} m_{\xi}(t) \cdot \cos \left(\frac{2 \pi}{T} t \cdot n\right) d t, n \in \mathbf{Z}$,

$b_{n}=\operatorname{Im}\left\{c_{n}\right\}=\frac{1}{T} \int_{0}^{T} m_{\xi}(t) \cdot \sin \left(\frac{2 \pi}{T} t \cdot n\right) d t, n \in \mathbf{Z}$.

Як приклад, на рисунках 2 та 3, подано результати розкладу у ряд Фур'є реалізації оцінок математичних сподівань електрокардіосигналу в II відведенні, які відповідають умовній нормі та патології.

Як видно із рисунків 2-4, а також це підтверджується багатьма експериментами, має місце факт значної чутливості оцінки математичного сподівання та коефіцієнтів іiі розкладу у ряд Фур'є, до зміни стану серцево-судинної системи людини, що вказує на можливість їх використання як діагностичних ознак в автоматизованих системах кардіодіагностики.

3 метою зменшення розмірності простору діагностичних ознак, при проведенні сумісного статистич- 

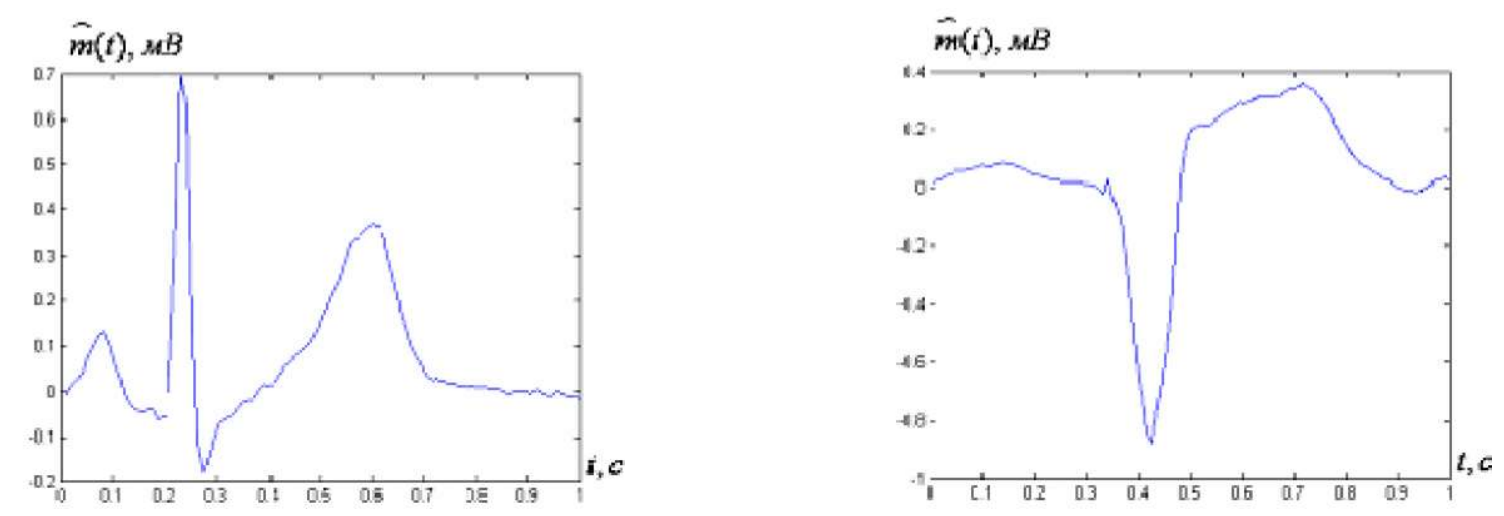

Puc. 2. Графіки реалізацій оцінок математичних сподівань електрокардіосигналів в II відведенні: а) діагноз: умовна норма; б) діагноз: нижній інфаркт міокарда.

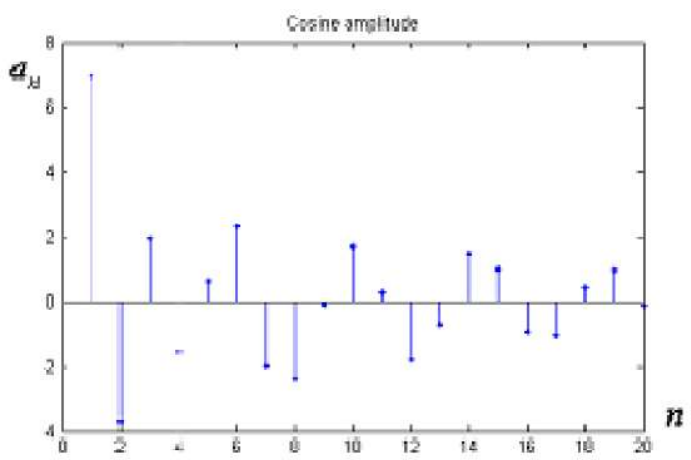

a

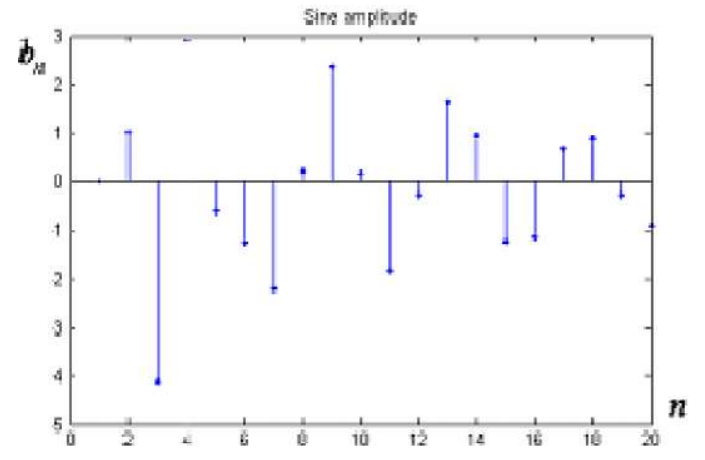

6

Puc. 3. Косинусний (а) та синусний (б) спектри реалізації оцінки математичного сподівання електрокардіосигналу в II відведенні (діагноз: умовна норма).

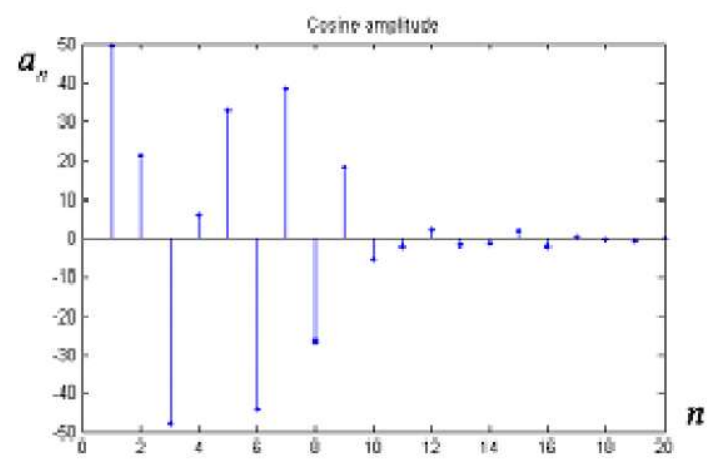

a

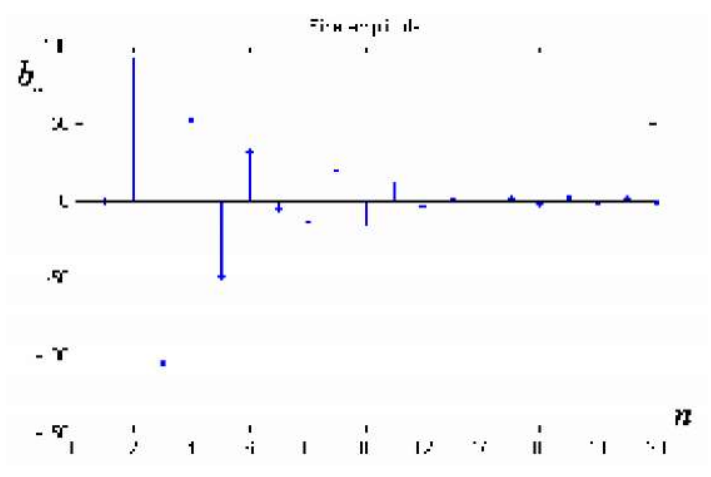

6

Puc. 4. Косинусний (а) та синусний (б) спектри реалізації оцінки математичного сподівання електрокардіосигналу в II відведенні (діагноз: нижній інфаркт міокарда).

ного аналізу синхронно зареєстрованих кардіосигналів, як діагностичні ознаки пропонується використовувати коефіцієнти ортогональних розкладів статистичних оцінок взаємних кореляційних функцій ком- понент СЗКС у двовимірний тригонометричний ряд Фур'є. Так, реалізацію статистичної оцінки взаємної кореляційної функції можна розкласти у двовимірний ряд Фур'є у комплексній формі, а саме:

$R_{\xi_{1}} \xi_{2}\left(t_{1}, t_{2}\right)=\sum_{n_{1}=-\infty}^{\infty} \sum_{n_{2}=-\infty}^{\infty} c_{n_{1}, n_{2}} \cdot e^{i\left[\frac{2 \pi}{T_{1}} t_{1} \cdot n_{1}+\frac{2 \pi}{T_{2}} t_{2} \cdot n_{2}\right]}, t_{1} \in\left[0, T_{1}\right), t_{2} \in\left[0, T_{2}\right)$, 
$\left\{e^{i\left[\frac{2 \pi}{T_{1}} t_{1} \cdot n_{1}+\frac{2 \pi}{T_{2}} t_{2} \cdot n_{2}\right]}, n_{1}, n_{2} \in \mathbf{Z}\right\}-$ двовимірний

тригонометричний ортогональний базис на області $\left[0, \mathrm{~T}_{1}\right) \times\left[0, \mathrm{~T}_{2}\right)$; множина $\left\{c_{n_{1}, n_{2}}, n_{1}, n_{2} \in \mathbf{Z}\right\} \in$ множиною спектральних коефіцієнтів, які визначаються згідно із формулою:

$$
c_{n_{1}, n_{2}}=\frac{1}{T_{1} \cdot T_{2}} \int_{0}^{T_{1}} \int_{0}^{T_{2}} R_{\xi_{1}} \xi_{2}\left(t_{1}, t_{2}\right) \cdot e^{-i\left[\frac{2 \pi}{T_{1}} t_{1} \cdot n_{1}+\frac{2 \pi}{T_{2}} t_{2} \cdot n_{2}\right]} d t_{1} d t_{2}, n_{1}, n_{2} \in \mathbf{Z},
$$

Коефіцієнти $\left\{c_{n_{1}, n_{2}}, n_{1}, n_{2} \in \mathbf{Z}\right\}$ загалом $\epsilon$ комплексними, а саме, мають таке зображення:

$$
c_{n_{1}, n_{2}}=a_{n_{1}, n_{2}}-i \cdot b_{n_{1}, n_{2}}, n_{1}, n_{2} \in \mathbf{Z} \text {, }
$$

де множини коефіцієнтів $\left\{a_{n_{1}, n_{2}}, n_{1}, n_{2} \in \mathbf{Z}\right\}$ та $\left\{b_{n_{1}, n_{2}}, n_{1}, n_{2} \in \mathbf{Z}\right\} \in$ відповідно косинусним та синусним спектрами реалізації оцінки взаємної кореляційної функції $R \xi_{1} \xi_{2}\left(t_{1}, t_{2}\right)$, які визначаються так:

$$
\begin{aligned}
& a_{n_{1}, n_{2}}=\operatorname{Re}\left\{c_{n_{1}, n_{2}}\right\}=\frac{1}{T_{1} \cdot T_{2}} \int_{0}^{T_{1}} \int_{0}^{T_{2}} R_{\xi_{1}} \xi_{2}\left(t_{1}, t_{2}\right) \cdot \cos \left(\frac{2 \pi}{T_{1}} t_{1} \cdot n_{1}+\frac{2 \pi}{T_{2}} t_{2} \cdot n_{2}\right) d t_{1} d t_{2}, n_{1}, n_{2} \in \mathbf{Z}, \\
& b_{n_{1}, n_{2}}=\operatorname{Im}\left\{c_{n_{1}, n_{2}}\right\}=\frac{1}{T_{1} \cdot T_{2}} \int_{0}^{T_{1}} \int_{0}^{T_{2}} R_{\xi_{1}} \xi_{2}\left(t_{1}, t_{2}\right) \cdot \sin \left(\frac{2 \pi}{T_{1}} t_{1} \cdot n_{1}+\frac{2 \pi}{T_{2}} t_{2} \cdot n_{2}\right) d t_{1} d t_{2}, n_{1}, n_{2} \in \mathbf{Z},
\end{aligned}
$$

На рисунках 5-13 подано результати таких розкладів реалізації статистичних оцінок взаємних кореляційних функцій компонент СЗКС, зокрема, синх-

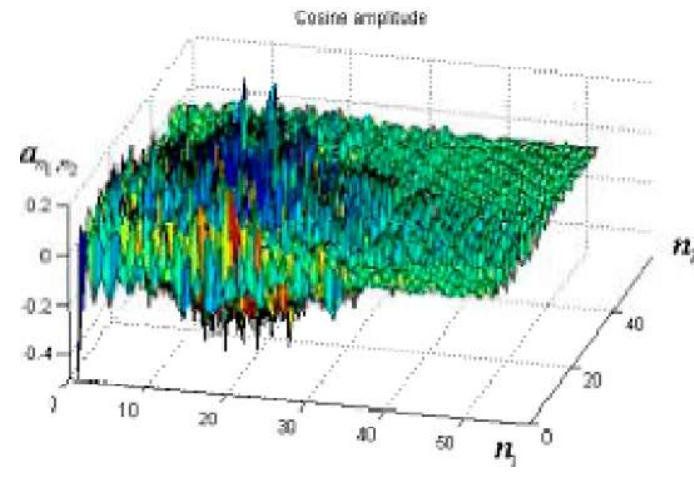

a ронно зареєстрованих електрокардіосигналів (СЗЕКС) в II та V відведеннях, які відповідають умовній нормі та деяким патологіям.

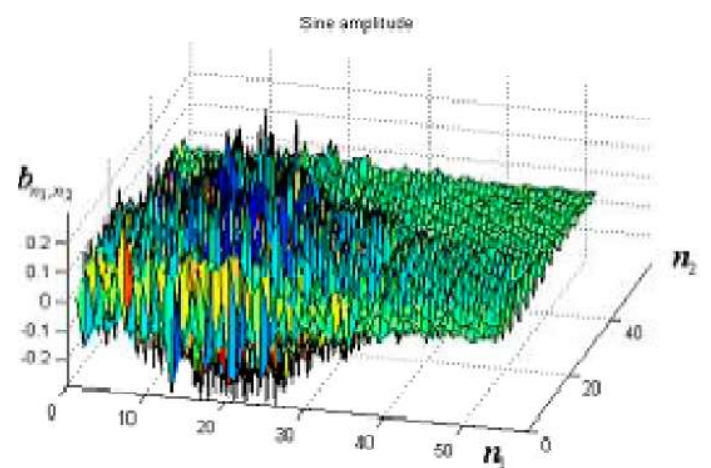

6

Puc. 5. Косинусний (а) та синусний (б) спектри реалізації оцінки взаємної кореляційної функції СЗЕКС в II та V відведеннях (діагноз: умовна норма).
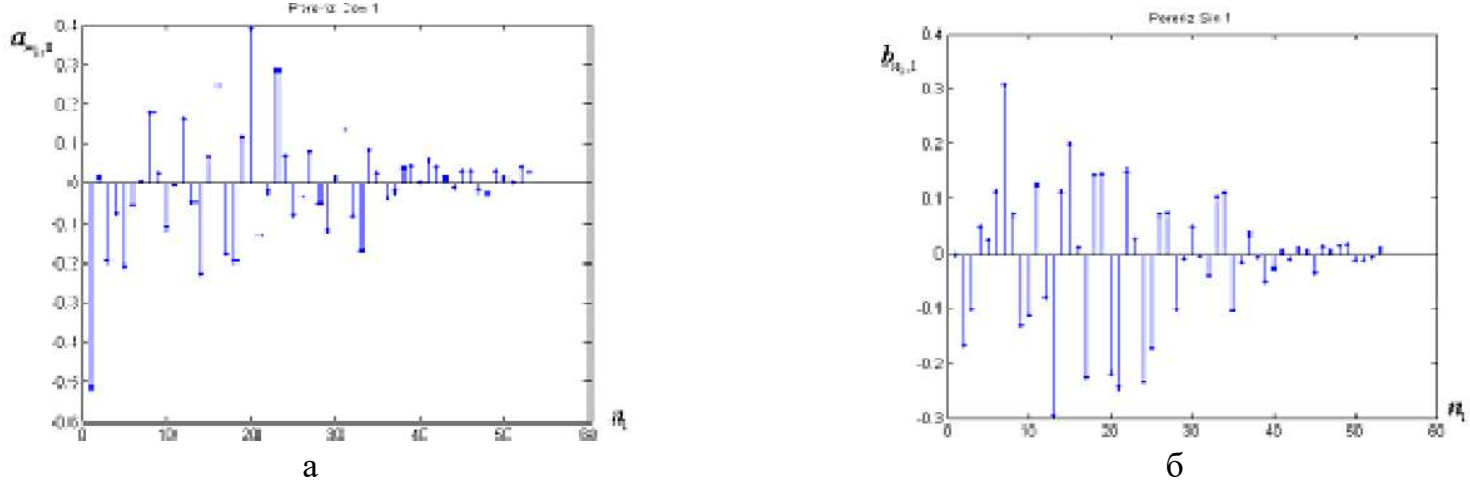

Puc. 6. Перерізи косинусного (а) та синусного (б) спектрів реалізації оцінки взаємної кореляційної функції СЗЕКС в II та V відведеннях (діагноз: умовна норма). 

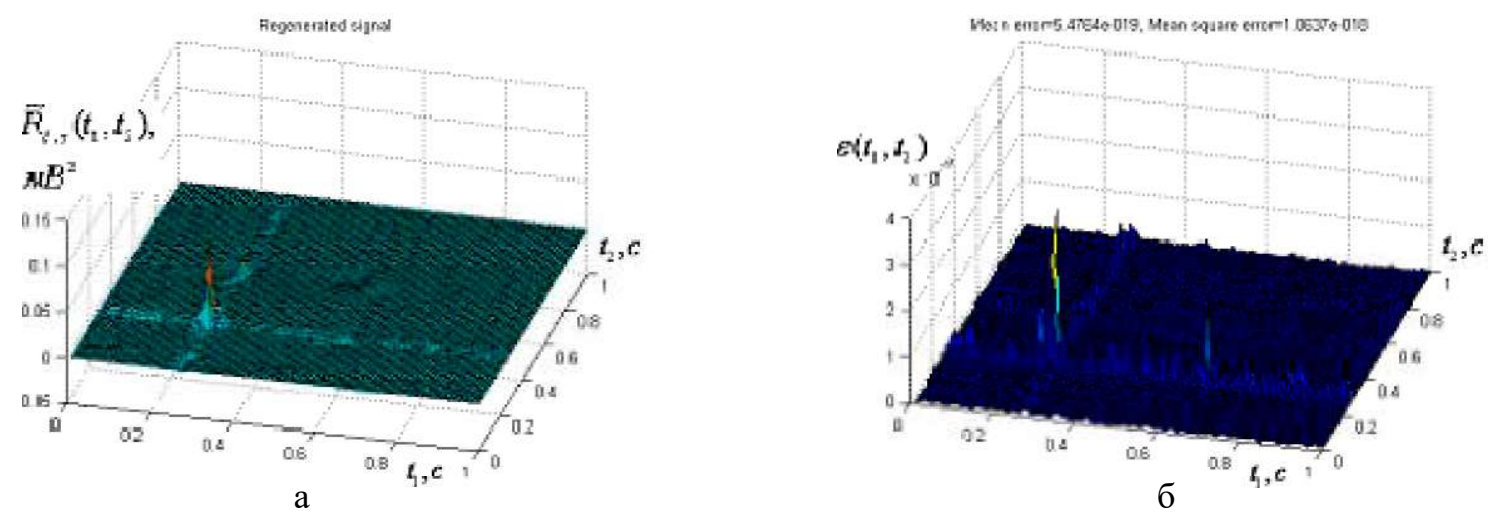

Puc. 7. Апроксимація (а) та похибка апроксимації (б) реалізації оцінки взаємної кореляційної функції СЗЕКС в II та V відведеннях (діагноз: умовна норма).
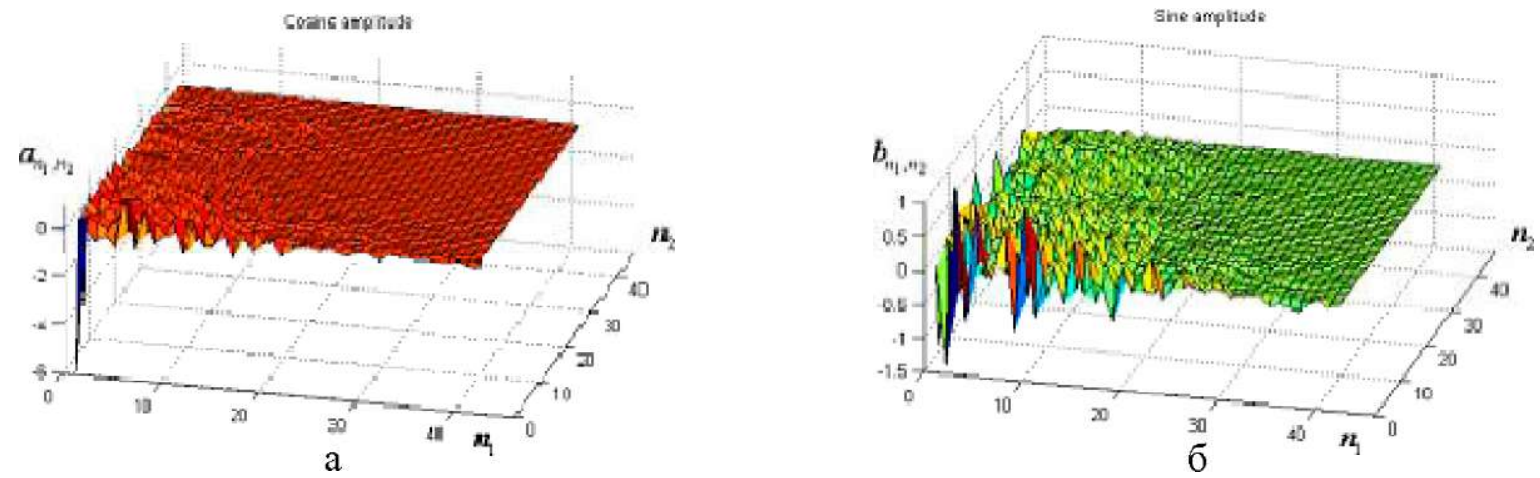

Puc. 8. Косинусний (а) та синусний (б) спектри реалізації оцінки взаємної кореляційної функції СЗЕКС в II та V відведеннях (діагноз: гіпертрофія правого шлуночка та правого передсердя).
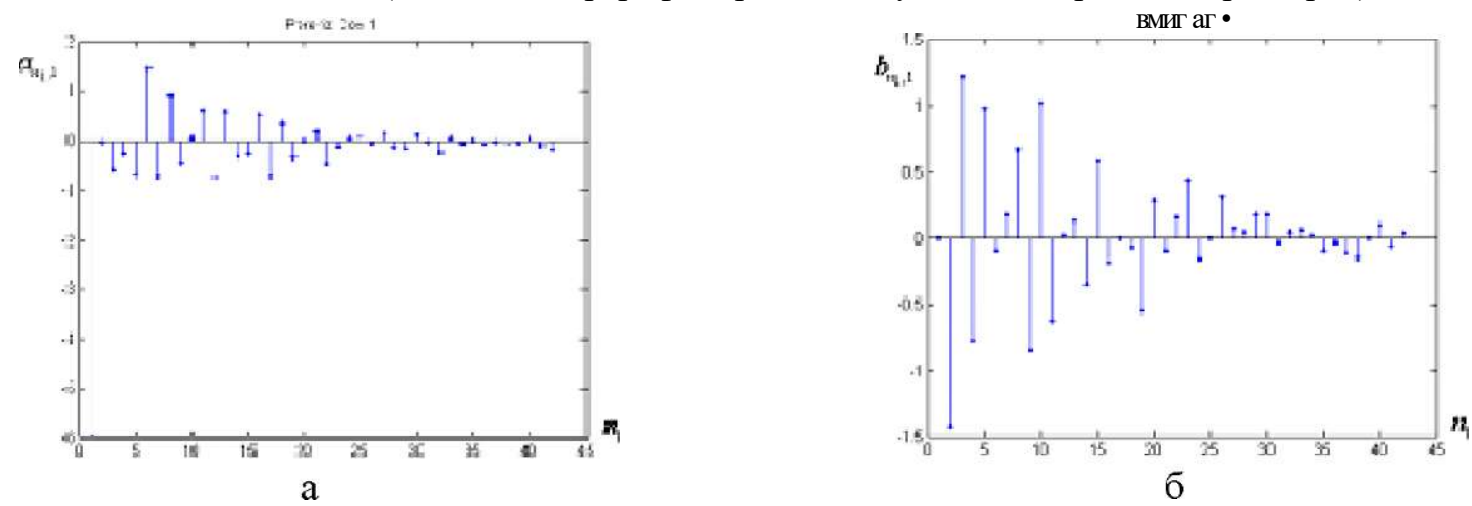

Puc. 9. Перерізи косинусного (а) та синусного (б) спектрів реалізації оцінки взаємної кореляційної функції CЗЕКС в II та V відведеннях (діагноз: гіпертрофія правого шлуночка та правого передсердя).
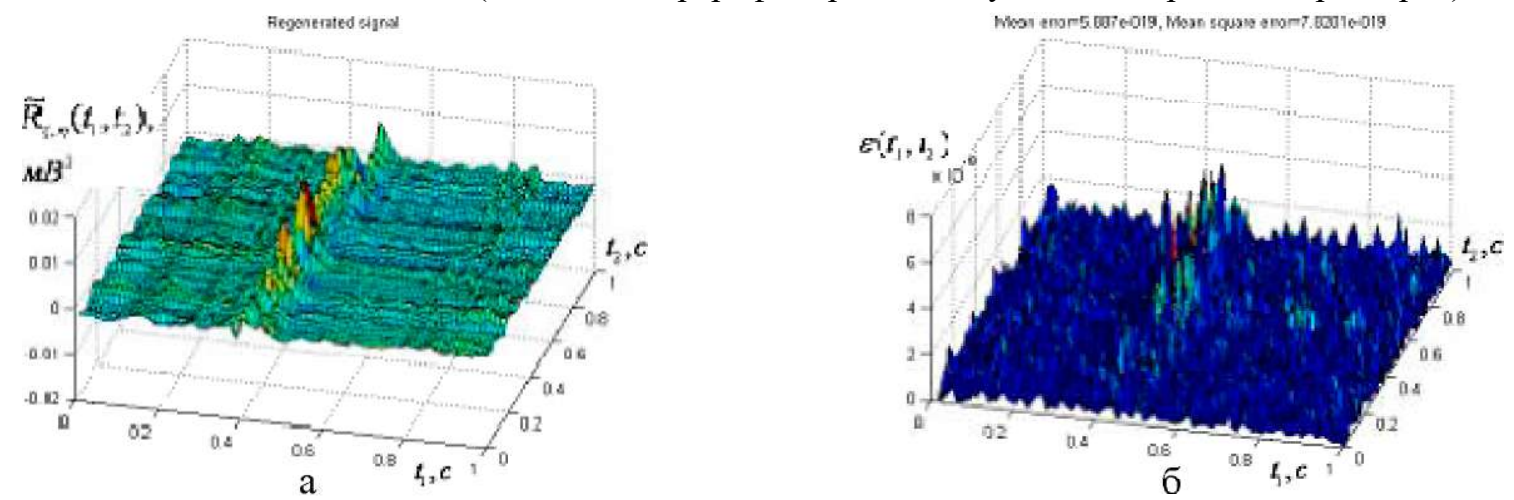

Puc. 10. Апроксимація (а) та похибка апроксимації (б) реалізації оцінки взаємної кореляційної функції

СЗЕКС в II та V відведеннях (діагноз: гіпертрофія правого шлуночка та правого передсердя). 

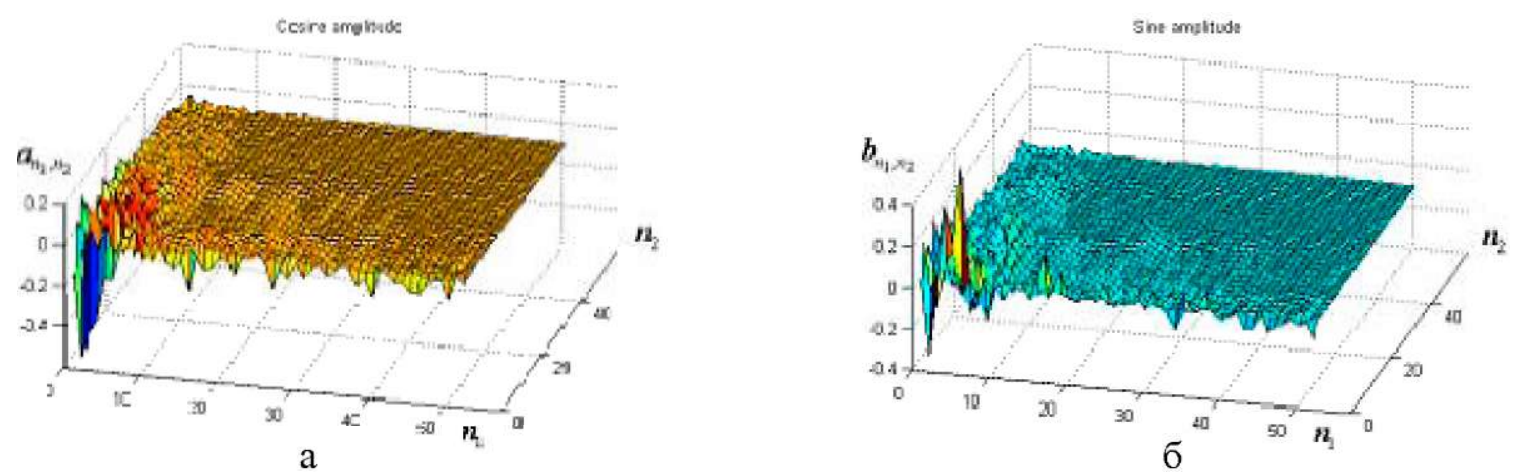

Puc. 11. Косинусний (а) та синусний (б) спектри реалізації оцінки взаємної кореляційної функції СЗЕКС в II та V відведеннях (діагноз: нижній інфаркт міокарда).

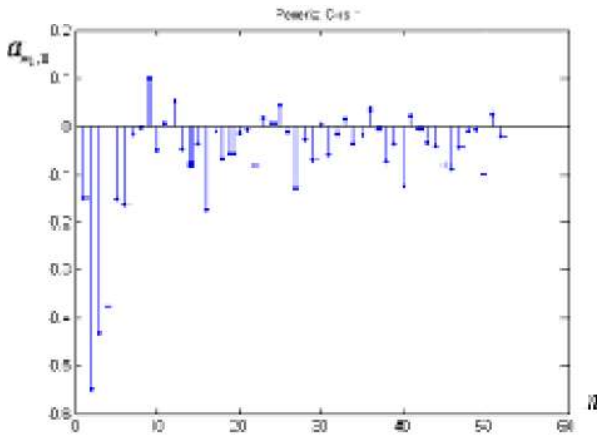

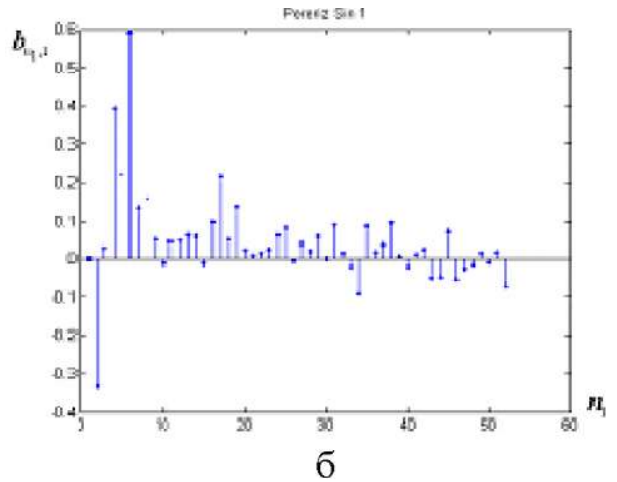

Puc. 12. Перерізи косинусного (а) та синусного (б) спектрів реалізації оцінки взаємної кореляційної функції СЗЕКС в II та V відведеннях (діагноз: нижній інфаркт міокарда).
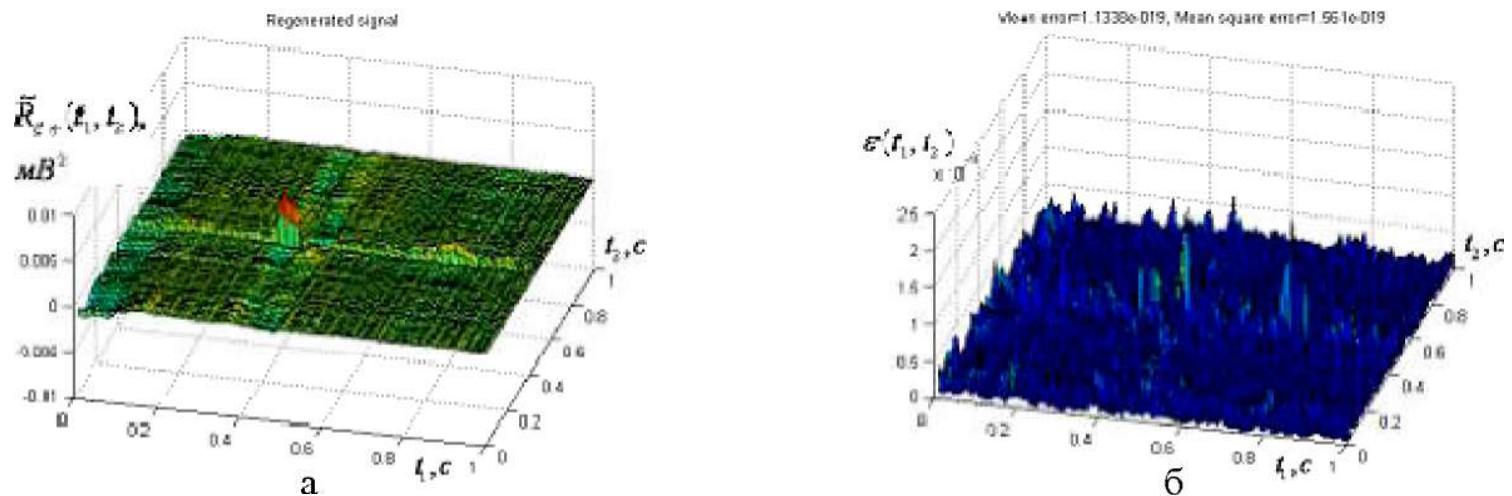

Puc. 13. Апроксимація (а) та похибка апроксимації (б) реалізації оцінки взаємної кореляційної функції

СЗЕКС в II та V відведеннях (діагноз: нижній інфаркт міокарда).

Як видно з рисунків 5-13, а також це підтверджується багатьма іншими експериментами, має місце факт значної чутливості оцінки взаємної кореляційної функції та коефіцієнтів їі розкладу у двовимірний ряд Фур'є, до зміни стану серцево-судинної системи людини, що вказує на можливість їх використання як діагностичних ознак в автоматизованих системах комплексної кардіодіагностики.

За критерій вибору необхідних спектральних коефіціснтів розкладу реалізації оцінки математичного сподівання досліджуваного кардіосигналу у ряд Фур' $\epsilon$ та реалізації оцінки взаємної кореляційної функції компонент СЗКС у двовимірний ряд Фур' є, вибрано енер- гетичний критерій, а саме, як діагностичні ознаки використовуються ті спектральні коефіцієнти $\left\{a_{n}, b_{n}, n=\overline{1, N}\right\}$ та
$\left\{a_{n_{1}, n_{2}}, b_{n_{1}, n_{2}}, n_{1}=\overline{1, N_{1}}, n_{2}=\overline{1, N_{2}}\right\}$, які, згідно із нерівністю Бесселя, роблять внесок у енергію реалізації статистичної оцінки математичного сподівання кардіосигналу та у енергію реалізації статистичної оцінки взаємної кореляційної функції компонент СЗКС не менше ніж $95 \%$. 
Висновок. У роботі обгрунтовано спектральні коефіцієнти розкладу реалізацій статистичних оцінок математичних сподівань кардіосигналів та взаємних кореляційних функцій синхронно зареєстрованих кардіо-

\section{Література}

1. Лупенко С. Математичне моделювання сигналів серця в задачах технічної кардіометрії на базі їх моделі у вигляді циклічного випадкового процесу / Лупенко С., Студена Ю. // Вісник Тернопільського державного технічного університету. - 2006. - Т. 11, № 1. - С. 134-142.

2. Сверстюк А. С. Обгрунтування та верифікація математичної моделі синхронно зареєстрованих кардіосигналів 3 використанням вектора циклічних ритмічно пов'язаних випадкових процесів / А. С. Сверстюк// Вимірювальна та обчислювальна техніка в технологічних процесах. - 2009. №1.- C.143-147 сигналів у ряди Фур'є як діагностичних ознак в комп' ютерних системах автоматизованої кардіодіагностики, що суттєво зменшує вимоги до обчислювальної продуктивності комп'ютерних кардіодіагностичних систем.

3. Лупенко С. А. Статистичний сумісний аналіз кардіосигналів на основі вектора циклічних ритмічно пов'язаних випадкових процесів / С. А. Лупенко, Я. В. Литвиненко, А. С. Сверстюк // Електроніка та системи управління. Національний авіаційний університет. - 2008. - № 4 (18). - С. 22-29. 4. Лупенко С. Сумісна статистична обробка синхронно зареєстрованих кардіосигналів на базі їх моделі у вигляді циклічнихритмічно пов'язаних випадкових процесів / С. Лупенко, Я. Литвиненко, А. Сверстюк // Тези доповідей дванадцятої наукової конференції Тернопільського державного технічного університету імені Івана Пулюя. - Тернопіль. 2008. - С. 111. 